\title{
Analisa Keausan Pahat pada Pemesinan Bor Magnesium AZ31 Menggunakan Metode Taguchi
}

\author{
Gusri Akhyar Ibrahim ${ }^{1}$, Joni Iskandar ${ }^{2}$, Arinal Hamni ${ }^{1}$, Sri Maria Puji Lestari ${ }^{2}$ \\ ${ }^{1}$ Jurusan Teknik Mesin Universitas Lampung \\ ${ }^{2}$ Jurusan Teknik Mesin, Fakultas Teknik Universitas Malahayati \\ e-mail: gusri.akhyar@eng.unila.ac.id
}

\begin{abstract}
Abstrak
Pengeboran (drilling) adalah proses pembuatan lubang dengan cara menekan sebuah mata pahat yang berputar pada benda kerja. Selama proses permesinan terjadi interaksi antara mata bor dengan benda kerja dimana benda kerja terpotong sedangkan mata bor mengalami gesekan. Gesekan yang dialami pahat berasal dari permukaan geram yang mengalir dan permukaan benda kerja yang telah terpotong, akibat gesekan ini pahat mengalami aus. Tujuan penelitian ini akan menganalisa umur pakai pahat HSS pada pemesinan bor magnesium AZ31 dan untuk mendukung penelitian tersebut digunakan Metode Taguchi untuk menganalisa pembahsan hasil penelitian. Parameter permesinan bor yang digunakan yaitu; mata bor HSS (hight speed stell) dengan ukuran (10 mm, $12 \mathrm{~mm}$, dan $14 \mathrm{~mm}$ ), kecepatan putaran (635 Rpm, 970 Rpm, 1420 Rpm) dan menggunakan gerak makan $(0,10 \mathrm{~mm} / \mathrm{rev}, 0,18 \mathrm{~mm} / \mathrm{rev}$ dan 0,24 mm/rev), dengan kedalam potong $50 \mathrm{~mm}$. Pengambilan data keausan pahat dilakukan menggunakan mikroskope digital USB dengan perbesaran 50x. Data keausan pahat dilihat setiap satu kali proses pengeboran dan proses pemesinan akan dihentikan jika mata bor sudah mengalami aus. Umur pahat tertinggi diperoleh pada diameter bor $10 \mathrm{~mm}$ dengan kecepatan putaran $635 \mathrm{rpm}$ dan menggunakan gerak makan $0,10 \mathrm{~mm} / \mathrm{rev}$ yaitu selama 12,74 menit, sedangkan umur pahat terendah diperoleh pada diameter bor $14 \mathrm{~mm}$ dengan kecepatan putaran $1420 \mathrm{rpm}$ dan menggunakan gerak makan sebesar 0,18 mm/rev yaitu selama 0,68 menit. Berdasarkan analisys of varian (ANOVA) parameter yang signifikan dalam mempengaruh umur pakai mata bor adalah kecepatan putaran (n). Semakin besar kecepatan putaran (n) maka keausan mata bor akan semakin cepat terjadi, hal tersebut disebabkan karena suhu tinggi yang di hasil dari gesekan antara mata bor dan benda kerja.
\end{abstract}

Kata kunci: kecepatan putaran, gerak makan, umur pahat, HSS, magnesium AZ31, ANOVA, aus.

\section{PENDAHULUAN}

Magnesium adalah logam yang ringan oleh sebab itu sangat sesuai untuk menggantikan komponen-komponen atau produk yang relatif berat. Magnesium dan paduannya sekarang semakin dikenal luas karena memainkan peranan penting dalam produk-produk otomotif, elektronik dan kesehatan Pengurangan berat komponen otomotif akan mengurangi berat keseluruhan kendaraan dan dengan demikian kendaraan yang relatif ringan akan dapat menghemat pemakaian bahan bakar (fuel consumption saving). Kemudian penggunaan magnesium pada produk elektronik seperti laptop, kamera juga untuk mengurangi berat produk [1, 2].

Paduan magnesium dan magnesium murni memiliki sifat ringan, mudah terbakar dan mudah bereaksi dengan logam lain. Oleh karena itu, magnesium tidak cukup kuat dalam bentuk yang murni, sehingga magnesium dipadukan dengan berbagai elemen untuk mendapatkan sifat yang lebih baik, terutama kekuatan untuk rasio berat yang tinggi. Banyak antara paduan magnesium sesuai untuk proses pengecoran, pembentukan, dan pemesinan untuk mendapatkan kualitas komponen yang baik. Salah satu sifat magnesium yang dominan adalah mudah beroksidasi dengan cepat (pyrophpric), sehingga ada resiko/bahaya kebakaran yang mungkin terjadi, oleh karena itu perlu ada tindakan pencegahan yang harus diambil ketika proses permesinan [2]. Pengeboran (drilling) adalah proses pembuatan lubang dengan cara menekan sebuah mata pahat yang berputar pada benda kerja. Salah satu permasalahan utama yang sering muncul adalah keausan pada pahat bor. Selama proses permesinan terjadi interaksi antara mata bor dengan benda kerja dimana benda kerja terpotong sedangkan mata bor mengalami gesekan. Gesekan yang dialami pahat berasal dari permukaan geram yang mengalir dan permukaan benda kerja yang telah terpotong, akibat gesekan ini pahat mengalami aus. Keausan pahat ini akan makin membesar sampai batas tertentu sehingga pahat tidak 
dapat dipergunakan lagi atau pahat telah mengalami kerusakan [3].

Dalam proses permesinan bor ada beberapa variabel yang mempengaruhi keausan pahat, seperti dalam penelitian Dodi, dkk. [4] menyatakan bahwa peningkatan gerak makan(f) dan peningkatan nilai kecepatan putaran (n) akan meningkatkan keausan tepi pahat, dan pemberian pelumas akan mengurangi keausan yang terjadi pada pahat. Dalam penelitian Ruslan dan Dalimunthe [5] juga dijelaskan bahwa ada beberpa faktor-faktor yang menentukan umur pahat adalah geometri pahat, jenis material benda kerja dan pahat, kondisi pemotongan (kecepatan potong, kedalaman potong dan gerakmakan), cairan pendingin.

\section{TINJAUAN PUSTAKA}

\section{Magnesium}

Magnesium adalah logam yang paling ringan diantara logam yang biasa digunakan dalam suatu struktur. Selain itu magnesium merupakan elemen terbanyak kedelapan yang membentuk $2 \%$ berat kulit bumi serta merupakan unsur terlarut ketiga terbanyak pada air laut. Dengan unsur yang melimpah tersebut maka wajar jika magnesium dijadikan bahan alternatif besi dan baja [6].

\section{Keausan Pahat}

Keausan pahat adalah sebuah fenomena yang sering terjadi dalam engineering. Keausan pahat akan timbul dengan sendirinya dalam proses pemotongan logam. Kompleksitas yang mengelilingi keausan pahat bersumber dari berbagai faktor meliputi material yang diproses, alat pemesinan, alat potong, pendingin dan kondisi pemotongan. Selama pemesinan, alat potong berinteraksi langsung dengan material [7].

\section{Metode Taguchi}

Metode Taguchi adalah metode eksperimen yang bertujuan untuk memperbaiki kualitas dari suatu produk dan proses dalam waktu yang bersamaan untuk menekan biaya dan sumber daya seminimal mungkin sehingga dicapai kondisi yang optimal dan efisien $[8,9]$

\section{METODOLOGI PENELITIAN}

Bahan material yang digunakan adalah magnesium AZ31 dengan panjang material $20 \mathrm{~cm}$ dan lebar $20 \mathrm{~cm}$ dengan ketebalan $5 \mathrm{~cm}$. Paduan magnesium AZ31 (Kandungan Al 3\% dan Kandungan Zink 1\%). Peralatan utama yang digunakan adalah mesin bor yang bermerek Erlo, dan pahat bubut HSS. Sedangkan aus pahat diukur menggunakan mikroskop digital. Proses pemotongan paduan magnesium menggunakan mesin bor dilakukan pada kondisi parameter pemotongan; diameter bor berukuran $10 \mathrm{~mm}, 12 \mathrm{~mm}, 14 \mathrm{~mm}$, dan kecepatan putaran sebesar 636 rpm, 970 rpm, 1420 $\mathrm{rpm}$, serta gerak makan sebesar $0,10 \mathrm{~mm} / \mathrm{rev}, 0,18$ $\mathrm{mm} / \mathrm{rev}$, dan $0,24 \mathrm{~mm} / \mathrm{rev}$. Percobaan dilakukan sampai mata bor mengalami aus, metode pengambilan data yaitu dengan mencatat hasil dari setiap selesai melakukan satu kali proses pengeboran

Alat yang digunakan untuk mengukur keausan tepi pahat adalah microscope digital. Dalam hal ini besarnya keausan tepi dapat diketahui dengan mengukur panjang VB (mm), yaitu jarak antara mata potong yang terjadi aus sampai kegaris rata-rata bekas aus, pada bidang pengukuran aus dilakukan semaksimal mungkin agar memperoleh hasil pengukuran yang lebih akurat dan meminimalisir nilai kesalahan. Rancangan eksperimen ini diawali dengan pemilihan matriks orthogonal yang tergantung dari banyaknya variabel kontrol dan level dari masingmasing variabel tersebut. Tabel 1 menunjukkan jumlah faktor, jumlah level dan nilai dari faktor yang digunakan pada penelitian ini.

Tabel 1. Jumlah faktor dan pengaturan level

\begin{tabular}{cccccc}
\hline & Faktor & & Level 1 & Level 2 & Level 3 \\
\hline A. & Dia. pahat bor & $\mathrm{mm}$ & 10 & 12 & 14 \\
B. & Kec. putaran & $\mathrm{rpm}$ & 635 & 970 & 1420 \\
C. & Gerak makan & $\mathrm{m} / \mathrm{rev}$ & 0,10 & 0,18 & 0,24 \\
\hline
\end{tabular}

Berdasarkan banyaknya jumlah faktor dan jumlah level dilakukan perhitungan derajat kebebasan untuk menentukan Matrik ortogonal yang digunakan, dapat dilihat pada Tabel 2 berikut ini.

Tabel 2. Total derajat kebebasan faktor dan levelnya

\begin{tabular}{clcc}
\hline No & \multicolumn{1}{c}{ Faktor } & level $(\mathrm{k})$ & Vn (k-1) \\
\hline 1 & Diameter mata bor & 3 & 2 \\
2 & Kecepatan potong & 3 & 2 \\
3 & Gerak makan & 3 & 2 \\
& $\begin{array}{l}\text { Total derajat } \\
\text { kebebasan }\end{array}$ & & 6 \\
\hline
\end{tabular}


Berdasarkan hasil perhitungan pada Tabel 2 didapatkan 6 derajat kebebasan untuk rancangan eksperimen ini, sehingga matrik ortogonal yang digunakan adalah L9 $\left(3^{2}\right)$. Matrik ortogonal jenis L9 memiliki 3 kolom dan 9 baris yang mampu digunakan untuk tiga buah variabel bebas yang masing-masing memiliki 3 level. Rancangan eksperimen untuk penelitian ini dapat dilihat pada Tabel 3 berikut ini.

Tabel 3. Matrik orthogonal L9

\begin{tabular}{cccc}
\hline & \multicolumn{3}{c}{ Parameter Pemesinan } \\
\cline { 2 - 4 } & Dia. Mata Bor & $\begin{array}{c}\text { Kecepatan } \\
\text { Potong }\end{array}$ & $\begin{array}{c}\text { Gerak } \\
\text { Makan }\end{array}$ \\
1 & 1 & 1 & 1 \\
2 & 1 & 2 & 2 \\
3 & 1 & 3 & 3 \\
4 & 2 & 4 & 2 \\
5 & 2 & 5 & 3 \\
6 & 2 & 6 & 1 \\
7 & 3 & 7 & 3 \\
8 & 3 & 8 & 1 \\
9 & 3 & 9 & 2 \\
\hline
\end{tabular}

Pengambilan data eksperimen dilakukan secara berurut dengan kombinasi parameter mengacu pada rancangan percobaan yang sesuai dengan matrik ortogonal pada Tabel 3. Pada setiap kombinasi parameter, eksperimen akan dilakukan sampai mata bor mengalami aus.

\section{HASIL DAN PEMBAHASAN}

Data yang diambil dari penelitian ini adalah nilai keausan pahat dan waktu pengeboran. Dimana pahat yang digunakan adalah pahat HSS Twist drill dan bahan yang digunakan adalah magnesium AZ31. Proses pengukuran nilai keausan pahat bor menggunakan alat microscope digital. Pengukuran keausan dilakukan pada tiap satu kali proses permesinan. Data hasil pengujian berupa nilai lamanya pemotongan dan kadar aus pahat potong, sebagaimana yang ditunjukan pada Tabel 4.

Tabel 4. Data hasil pengujian

\begin{tabular}{cccccc}
\hline No & $\begin{array}{c}\mathrm{D} \\
(\mathrm{mm})\end{array}$ & $\begin{array}{c}\mathrm{n} \\
(\mathrm{rpm})\end{array}$ & $\begin{array}{c}\mathrm{f} \\
(\mathrm{mm} / \mathrm{rev})\end{array}$ & $\begin{array}{c}\mathrm{t} \\
(\text { detik})\end{array}$ & $\begin{array}{c}\mathrm{Vb} \\
(\mathrm{mm})\end{array}$ \\
\hline 1 & 10 & 635 & 0,10 & 12,74 & 0,056 \\
2 & 10 & 970 & 0,18 & 2,77 & 0,074 \\
3 & 10 & 1420 & 0,24 & 0,76 & 0,082 \\
4 & 12 & 636 & 0,18 & 2.91 & 0,064 \\
\hline
\end{tabular}

\begin{tabular}{cccccc}
\hline 5 & 12 & 970 & 0,24 & 0,92 & 0,088 \\
6 & 12 & 1420 & 0,10 & 1,50 & 0,092 \\
7 & 14 & 635 & 0,24 & 2,59 & 0,057 \\
8 & 14 & 970 & 0,10 & 1,70 & 0,063 \\
9 & 14 & 1420 & 0,18 & 0,68 & 0,070 \\
\hline
\end{tabular}

\section{Analyze Taguchi Design}

Berikut ini merupakan analisa kuantitatif menggunakan program minitab 16 analisis desain Metode Taguchi. Untuk mengetahui faktor apa yang paling berpengaruh dan signifikan terhadap keausan mata bor HHS (hight speet stell) twist drill dalam proses pengeboran bahan magnesium AZ31.Dalam analisis tersebut akan ditampilkan data hasil analisis Taguchi berdasarkan waktu yang dibutuhkan dalam setiap tahap percobaan. Perhitungan S/N rasio berdasarkan waktu pemotongan adalah sebagaimana yang ditunjukan pada Tabel 5.

Tabel 5. Hasil percobaan untuk umur pakai mata bor dan perhitungan $\mathrm{S} / \mathrm{N}$ rasio

\begin{tabular}{cccccc}
$\begin{array}{c}\text { Exp. } \\
\text { run }\end{array}$ & $\begin{array}{c}\mathrm{D} \\
(\mathrm{mm})\end{array}$ & $\begin{array}{c}\mathrm{n} \\
(\mathrm{rpm})\end{array}$ & $\begin{array}{c}\mathrm{f} \\
(\mathrm{mm} / \mathrm{rev})\end{array}$ & $\begin{array}{c}\mathrm{t} \\
(\mathrm{menit})\end{array}$ & $\mathrm{S} / \mathrm{N}$ \\
\hline 1 & 1 & 1 & 1 & 12.74 & 22.1034 \\
2 & 1 & 2 & 2 & 2.77 & 8.8496 \\
3 & 1 & 3 & 3 & 0.76 & -2.3837 \\
4 & 2 & 1 & 2 & 2.91 & 9.2779 \\
5 & 2 & 2 & 3 & 0.92 & -0.7242 \\
6 & 2 & 3 & 1 & 1.50 & 3.5218 \\
7 & 3 & 1 & 3 & 2.59 & 8.2660 \\
8 & 3 & 2 & 1 & 1.70 & 4.6090 \\
9 & 3 & 3 & 2 & 0.68 & -3.3498 \\
\hline
\end{tabular}

Pada Tabel 5 menunjukkan data aktual keausan mata bor dengan nilai $\mathrm{S} / \mathrm{N}$ rasio. pada kolom exp. Run menunjukan nomor urutan penelitian yang akan dilakukan. Pada kolom $D$ (diameter) menujukkan diameter mata bor yang digunakan, lambang angka 1 menunjukkan diameter bor yang digunakan $10 \mathrm{~mm}$, lambang 2 menunjukkan diameter bor $12 \mathrm{~mm}$, lambang 3 menggunakan diameter14 mm. pada kolom $n$ (kecepatan putaran) menunjukkan parameter kecepatan putaran yang digunakan, lambang 1 menunnjukkan kecepatan putaran 635 rpm, lambang 2 menunjukkan kecepatan putaran 970 Rpm, dan lambang 3 menunjukkan kecepatan putaran 1420 rpm. Pada kolom $f$ (gerak makan) menunjukkan parameter gerak makan yang digunakan, lambang 1 menunjukkan gerak makan $0,10 \mathrm{~mm} / \mathrm{rev}$, lambang 2 menunjukkan gerak 
makan yang digunakan $0.18 \mathrm{~mm} / \mathrm{rev}$, lambang 3 menunjukkan gerak makan yang digunakan 0.24 $\mathrm{mm} / \mathrm{rev}$.

Adapun untuk menghitung Perhitungan nilai rasio $\mathrm{S} / \mathrm{N}$ tergantung pada jenis karakteristik kualitas dari respon. Respon umur pakai pahat memiliki karakteristik kualitas semakin lama semakin baik. Rasio S/N dari respon keausa pahat tersebut dihitung dengan menggunakan persamaan berikut. Contoh perhitungan rasio $\mathrm{S} / \mathrm{N}$ dari waktu penggunaan pahat untuk kombinasi setting faktor pertama dengan karakteristik kualitas semakin lama semakin baik adalah sebagai berikut:

$$
\begin{aligned}
& \frac{\mathrm{S}}{\mathrm{N}}=-10 \log \left[\frac{1}{\mathrm{n}} \sum_{\mathrm{i}=1}^{\mathrm{r}} \frac{1}{\mathrm{yi}^{2}}\right] \\
& \frac{\mathrm{S}}{N}(t)=-10 \log \left[\frac{1}{1}\left(\frac{1}{(12.74)^{2}}\right)\right] \\
& =-10 \log \left(\frac{1}{162,3076}\right)=22,1034 \\
& \frac{S}{N}(t)=22,1034
\end{aligned}
$$

Dimana $\mathrm{n}=$ jumlah replikasi data $\mathrm{t}$ (waktu) yang diambil $\mathrm{y}=$ nilai $(\mathrm{t})$ waktu yang didapatkan

\section{Analysis of Variant (ANOVA) for S/N Ratios}

Analysis of Variant (ANOVA) digunakan untuk mengetahui variable proses yang memiliki pengaruh secara signifikan. Dengan menggunakan softwere minitab 16 hasil ANOVA respon waktu pakai pahat dengan faktor diameter mata bor,

\begin{tabular}{|c|c|c|c|c|c|c|}
\hline Source & $\begin{array}{l}\text { D } \\
\text { F }\end{array}$ & $\begin{array}{l}\text { Seq } \\
\text { SS }\end{array}$ & $\begin{array}{l}\text { Adj } \\
\text { SS }\end{array}$ & $\begin{array}{l}\text { Adj } \\
\text { MS }\end{array}$ & $\mathrm{F}$ & $\mathrm{P}$ \\
\hline $\mathrm{d}(\mathrm{mm})$ & 2 & 71.25 & 71.25 & 35.624 & 4.83 & 0.172 \\
\hline n (rpm) & 2 & 299.98 & 299.98 & 149.992 & 20.33 & 0.047 \\
\hline $\begin{array}{c}\mathrm{f} \\
(\mathrm{mm} / \mathrm{re} \\
\mathrm{v})\end{array}$ & 2 & 106.70 & 106.70 & 53.348 & 7.23 & 0.122 \\
\hline $\begin{array}{l}\text { Error } \\
\text { (\%) }\end{array}$ & 2 & 14.76 & 14.76 & 7.379 & & \\
\hline Total & 8 & 492.69 & & & & \\
\hline
\end{tabular}
kecepatan putaran dan gerak makan. Maka dihasilkan data yang tampak pada Tabel 6 ANOVA berikut:

Tabel 6. Analisa varian untuk rasio $\mathrm{S} / \mathrm{N}$ waktu pakai pahat
Pada Tabel 6 dimana hasil pengolahan data menggunakan program minitab, pada kolom terakhir muncul huruf P. Itu merupakan satuan atau simbol dari nilai probabilitas ( $\mathrm{P}$ value), itu adalah peluang munculnya suatu kejadian. Besarnya peluang melakukan kesalahan disebut taraf signifikansi yang artinya meyakinkan atau berarti. Dalam penelitian ini mengandung arti bahwa hipotesis yang telah terbukti pada sampel dapat diperlakukan pada populasi. Tingkat signifikansi 5\% atau 0.050 artinya kita mengambil resiko kesalahan dalam mengambil keputusan untuk menolak hipotesis yang benar sebanyak-banyaknya 5\% dan dalam mengambil keputusan sedikitnya 95\% (tingkat kepercayaan). Lebih jelasnya, misalkan ada 100 kejadian dengan nilai probabilitas $5 \%$, artinya peluang munculnya kesalahan akan terjadi sebanyak 5 kali dalam 100 kejadian.

Dalam penelitian ini nilai $\mathrm{P}$ untuk diameter mata bor adalah 0,172, nilai $\mathrm{P}$ untuk kecepatan putaran adalah 0,047 dan nilai $\mathrm{P}$ untuk gerak makan adalah 0,122. Dari hasil data tersebut menunjukkan bahwa parameter kecepatan putaran menghasilkan nilai $\mathrm{P}<$ 0,050, hal ini menunjukkan bahwa parameter kecepatan putaran merupakan faktor yang signifikan dalam mempengaruhi penurunan umur pakai pahat bor. Sedangkan gerak makan dan diameter mata bor tidak memberikan pengaruh secara signifikan, namun parameter gerak makan memberikan kontribusi yang lebih besar dibandingkan parameter diameter bor. Gerak makan berkontribusi lebih besar dalam menurun umur pakai pahat. Hal tersebut dapat diamati melalui besaran nilai $\mathrm{P}$, dimana gerak makan memberikan nilia P sebesar 12,2\% dan lebih kecil disbanding nilai $\mathrm{P}$ untuk diameter pahat sebesar $17,2 \%$.

\section{Analisa respon nilai tabel dan grafik untuk $S / N$ ratio}

Untuk faktor kontrol dalam mengindifikasi pengaruh level dari faktor terhadap rata-rata waktu yang digunakan saat pengeboran dilakukan pengeolahan data respon (waktu pakai pahat) yang diperoleh langsung dari setiap tahap percobaan pengeboran Perhitungan waktu rata-rata umur pakai mata pahat melalui konbinasi level dari masinmasing faktor. Untuk respon umur pakai mata pahat, pengaruh level terlihat pada Tabel 7 berikut:

Tabel 7. Response Tabel for S/N Ratios $t$ (waktu) 


\begin{tabular}{|c|c|c|c|}
\hline Level & $\begin{array}{c}\text { Dia. mata } \\
\text { bor (mm) }\end{array}$ & $\begin{array}{c}\text { Kec. Putaran } \\
\text { (rpm) }\end{array}$ & $\begin{array}{c}\text { gerak makan } \\
\text { (mm/rev) }\end{array}$ \\
\hline 1 & 9.5231 & 13.2157 & 10.0781 \\
\hline 2 & 4.0251 & 4.2448 & 4.9259 \\
\hline 3 & 3.1751 & -0.7372 & 1.7193 \\
\hline Delta & 6.3480 & 13.9530 & 8.3587 \\
\hline Rank & 3 & 1 & 2 \\
\hline
\end{tabular}

Berdasarkan data hasil rata-rata $\mathrm{S} / \mathrm{N}$ rasio pada Tabel 7. didapat Gambar grafik respon S/N dapat dilihat pada Gambar 1 berikut ini.

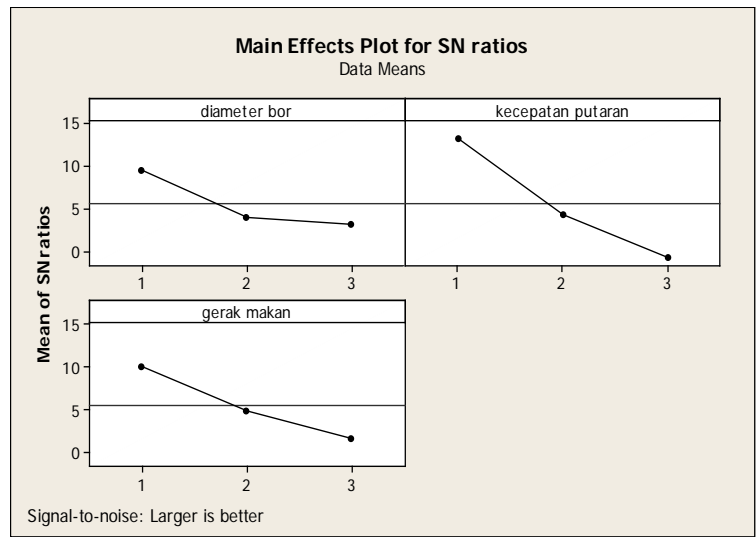

Gambar 1. Grafik S/N untuk respon nilai rata-rata waktu pakai mata bor

Berdasarkan analisa pada Tabel 7 dan Gambar 1, parameter yang mempengaruhi respon umur mata bor paling lama adalah pada diameter mata bor level 1, kecepatan putaran pada level 1, dan gerak makan pada level 1. Hal tersebut dapat dilihat pada Tabel 8 di bawah ini.

Tabel 8. Respon parameter terbaik

\begin{tabular}{|l|c|l|}
\hline \multicolumn{1}{|c|}{ Faktor } & Level & \multicolumn{1}{c|}{ Nilai Level } \\
\hline Dia. mata bor & Level 1 & $10 \mathrm{~mm}$ \\
\hline Kec. Putaran & Level 1 & $635 \mathrm{rpm}$ \\
\hline Gerak makan & Level 1 & $0,10 \mathrm{~mm} / \mathrm{rev}$ \\
\hline
\end{tabular}

Dari data tersebut dapat disimpulkan bahwa penggunaan kecepatan putaran dan gerak makan yang digunakan rendah maka nilai keausan yang dihasilkan akan rendah. Dengan kata lain bahwa penggunaan parameter kecepatan putaran dan gerak makan yang rendah maka akan memperpanjang umur penggunaan mata pahat. Hal ini didukung oleh penelitian sebelumnya yang menyatakan bahwa semakin kecil gerak makan daan kecepatan puataran maka keausan yang terjadi pada mata bor akan semakin lama [4].

\section{Analysis of Variance for Means waktu pakai pahat}

Analysis of Variance for Means merupakan analisis pembanding untuk memperkuat data anova $\mathrm{S} / \mathrm{N}$ ratios Taguchi untuk mengertahui parameter yang signifikan atau parameter yang mempengaruhi batas umur pakai mata pahat. Analisis varian for mean tersebut menghitung berdasarkan nilai rata-rata dari setiap para meter yang digunakan.

Analysis of Variant (ANOVA) digunakan untuk mengetahui variable proses yang memiliki pengaruh secara signifikan atau faktor yang berkontribusi dalam mempengaruhi umur pakai pahat. Dengan menggunakan softwere minitab 16 hasil ANOVA respon waktu pakai pahat dengan faktor diameter mata bor, kecepatan putaran dan gerak makan. Maka dihasilkan data yang tampak pada Tabel 9 ANOVA berikut:

Tabel 9 Analysis of Variance for Means untuk waktu pakai pahat

\begin{tabular}{|l|c|c|c|c|c|c|}
\hline Source & $\begin{array}{c}\text { D } \\
\text { F }\end{array}$ & $\begin{array}{c}\text { Seq } \\
\text { SS }\end{array}$ & $\begin{array}{c}\text { Adj } \\
\text { SS }\end{array}$ & $\begin{array}{c}\text { Adj } \\
\text { MS }\end{array}$ & F & P \\
\hline $\mathrm{d}(\mathrm{mm})$ & 2 & 27.50 & 27.50 & 13.750 & 1.79 & 0.359 \\
\hline $\mathrm{n}(\mathrm{rpm})$ & 2 & 45.02 & 45.02 & 22.512 & 2.92 & 0.255 \\
\hline $\begin{array}{c}\mathrm{f} \\
(\mathrm{mm} / \mathrm{rev})\end{array}$ & 2 & 25.81 & 25.81 & 12.907 & 21.68 & 0.374 \\
\hline $\begin{array}{l}\text { Residual } \\
\text { Error }\end{array}$ & 2 & 15.40 & 15.40 & 7.702 & & \\
\hline \begin{tabular}{c} 
Total \\
\hline
\end{tabular} & 8 & 113.74 & & & & \\
\hline
\end{tabular}

Dalam penelitian ini nilai diameter mata bor dengan nilai $\mathrm{P}=0,359$, nilai kecepatan putaran dengan nilai $\mathrm{P}=0,255$ dan nilai gerak makan dengan nilai $\mathrm{P}=0.374$. Dari data tersebut menyatakan bahwa tidak ada faktor yang signifikan dalam menurunkan umur pakai pahat, namun data tersebut menyatakan bahwa kecepatan putaran merupakan faktor yang paling berkontribusi dalam menurunkan umur pakai pahat, hal tersebut dapat dilihat dari nilai $\mathrm{P}$ yang dihasilkan lebih kecil dari ketiga faktor tersebut.

Dari data yang dihasilkan dalam Analysis of Variance for SN ratios menyatakan bahwa data yang signifikan dalam menurunkan umur pakai pahat adalah kecepatan putaran (n) sedangkan pada Analysis of Variance for means menyatakan bahwa tidak ada faktor yang signifikan dalam menurunkan umur pakai pahat, namun kecepatan putaran mendapatkan nilai $\mathrm{P}$ yang paling kecil dari ketiga faktor yang digunakan. 
Jadi dari hasil perhitung analisis anova $\mathrm{S} / \mathrm{N}$ ratio dan perhitungan analisi anova mean menunjukkan bahwa kecepatan putaran merupakan faktor yang paling berpengaruh terhadap umur pakai pahat.

\section{Analisa respon nilai Tabel dan grafik for means}

Untuk faktor kontrol dalam mengindifikasi pengaruh level dari faktor terhadap rata-rata waktu yang digunakan saat pengeboran dilakukan pengeolahan data respon (waktu pakai pahat) yang diperoleh langsung dari setiap tahap percobaan pengeboran, Perhitungan waktu rata-rata umur pakai mata pahat melalui konbinasi level dari masingmasing faktor. Untuk respon umur pakai mata pahat, pengaruh level terlihat pada Tabel 10 berikut:

Tabel 10. Response Tabel for Means waktu pakai pahat

\begin{tabular}{|c|c|c|c|}
\hline Level & $\begin{array}{c}\text { Dia. Mata } \\
\text { bor (mm) }\end{array}$ & $\begin{array}{c}\text { Kec. } \\
\text { Putaran } \\
\text { (rpm) }\end{array}$ & $\begin{array}{c}\text { Gerak makan } \\
(\mathrm{mm} / \mathrm{rev})\end{array}$ \\
\hline 1 & 5.4233 & 6.0800 & 5.3133 \\
\hline 2 & 1.7767 & 1.7967 & 2.1200 \\
\hline 3 & 1.6567 & 0.9800 & 1.4233 \\
\hline Delta & 3.7667 & 5.1000 & 3.8900 \\
\hline Rank & 3 & 1 & 2 \\
\hline
\end{tabular}

Berdasarkan data hasil rata-rata respon for mean pada Tabel 4.7 didapat Gambar grafik respon mean dapat dilihat pada Gambar 2 berikut ini.

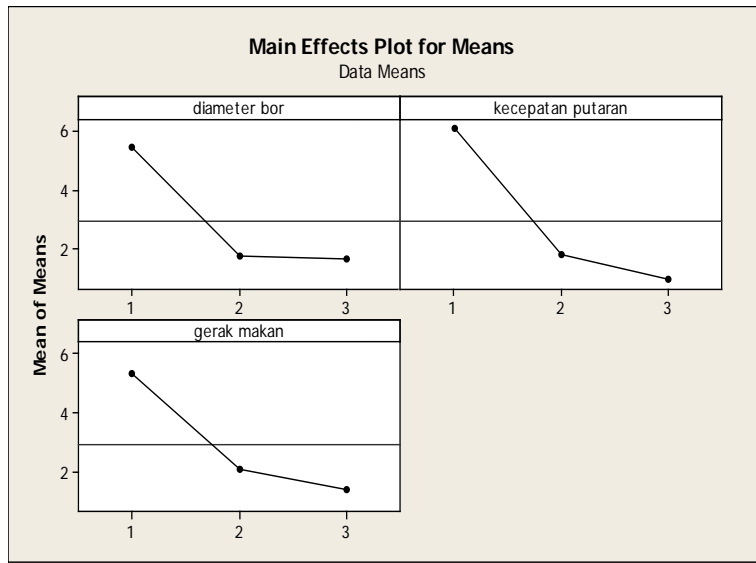

Gambar 2 Grafik mean untuk respon nilai rata-rata waktu pakai pahat

Berdasarkan analisa pada Tabel 10 dan Gambar 2, parameter yang mempengaruhi respon penurunan umur pakai mata bor adalah diameter mata bor pada level 3, kecepatan putaran pada level 3, dan gerak makan pada level 3 seperti pada Tabel 11 .

Tabel 11. Respon parameter terbaik

\begin{tabular}{|l|c|l|}
\hline \multicolumn{1}{|c|}{ Faktor } & Tingkatan Level & \multicolumn{1}{c|}{ Nilai Level } \\
\hline Dia. Mata bor & Level 1 & $10 \mathrm{~mm}$ \\
\hline Kec. Putaran & Level 1 & $635 \mathrm{rpm}$ \\
\hline Gerak makan & Level 1 & $0,10 \mathrm{~mm} / \mathrm{rev}$ \\
\hline
\end{tabular}

Berdasarkan analisa respon pada Tabel 11 menunjukkan bahwa yang mempengaruhi umur pakai pahat semakin berkurang adalah pada diameter mata bor $10 \mathrm{~mm}$, kecepatan putaran $635 \mathrm{rpm}$, dan gerak makan 0,10 mm/rev. Berdasarkan perbandingan hasil dari analisis Taguchi baik menggunakan analysis anova for $S / N$ ratio ataupun analysis anova for mean menunjukkan bahwa hasil kedua analisis tersebut menyatakan kecepatan putaran merupakan parameter yang paling berpengaruh dalam menurunkan umur pakai pahat, kemudian gerak makan merupakan faktor kedua dalam menurunkan umur pakai pahat, dan yang terakhir adalah diameter mata bor. Hal tersebut disebabkan karena semakin meningkat kecepatan putaran yang digunakan maka gesekan akan semakin besar sehingga suhu pemesinan akan semakin tinggi yang menyebabkan pahat cepat mengalami aus.

Dalam penelitian sebelumnya juga dikatakan bahwa laju keausan meningkat seiring dengan meningkatnya kecepatan potong. Hal ini disebabkan karena kenaikan gaya potong, besarnya gaya pemotongan akan memberikan tekanan yang besar pada pahat sehingga temperatur pemotongan meningkat, karena hampir seluruh energi pemotongan diubah menjadi panas melalui gesekan antara geram dengan pahat dan antara pahat dengan benda kerja [10].

Berdasarkan hasil analisa respon Tabel dan grafik dari kedua analisis tersebut menyatakan bahwa penggunaan kecepatan putaran yang kecil dan gerak makan yang kecil akan memperpanjang umur pakai pahat, begitupun sebaliknya, penggunaan para meter kecepatan putaran dan gerak makan yang tinggi akan menurunkan umur pakai pahat. Jadi semakin meningkatnya kecepatan putaran dan gerak makan yang digunakan maka keausan akan cepat terajdi, dan hal tersebut akan menurunkan umur pakai pahat. Dalam penelitian Dodi, dkk. [4] dikatakan bahwa semakin kecil gerak makan dan kecepatan puataran maka keausan yang terjadi pada mata bor akan semakin lama. 


\section{KESIMPULAN}

Berdasarkan hasil eksperimen dan analisis yang telah dilakukan, maka penelitian yang berjudul "Analisa Keausan Pahat Pada Pemesinan Bor Magnesium AZ31 Menggunakan Metode Taguchi” dapat diambil kesimpulan sebagai berikut:

1. Dari kesembilan percobaan yang dilakukan, dapat disimpulkan bahwa penggunaan kecepatan putaran dan gerak makan yang rendah akan memperpanjang umur penggunaan pahat, begitupun sebaliknya semakin meninggkatnya kecepatan putaran dan gerak makan yang digunakan maka umur pakai pahat akan semakin menurun, dan semakin besar diameter mata bor yang digunakan maka keausan mata bor juga akan cepat terjadi. Karena semakin meningkat kecapatan putaran, gerak makan dan diameter mata bor yang digunakan maka suhu permesinan akan semakin meningkat, sehingga menyebabkan mata bor cepat terjadi aus.

2. Semua keuasan mata bor terjadi pada sisi ujungnya dan pada sisi tepinya, mekanisme ini mengindikasikan bahwa terjadinya keausan tepi (flank wear). Penyebab keausan ini terjadi karena adanya gesekan antara permukaan benda kerja dengan pahat, dimana pada bagian sisi tepi dan sisi ujung mata bor merupakan permukaan utama saat melakukan pemakanan.

3. Dari hasil Metode Taguchi berdasarkan analisis anova nilai $\mathrm{S} / \mathrm{N}$ ratio dan analisis anova nilai rata-rata waktu yang digunakan, menyatakan bahwa parameter yang signifikan atau berpengaruh dalam menurunkan umur pakai pahat adalah kecepatan putaran. Karena semakin meningkat kecepatan putaran yang digunakan maka gesekan akan semakin besar sehingga suhu pemesinan akan semakin tinggi yang menyebabkan pahat cepat mengalami aus, sedangkan berdasarkan analisa respon Tabel dan grafik, parameter yang mempengaruhi umur pakai pahat adalah sebagai berikut:

a. Diameter mata bor pada level 1 adalah 10 $\mathrm{mm}$, kecepatan putaran pada level 1 adalah $635 \mathrm{rpm}$, gerak makan pada level 3 adalah 0,10 mm. Maka umur pakai mata akan semakin panjang, Sedangkan

b. Pada diameter mata bor pada level 3 adalah $14 \mathrm{~mm}$, kecepatan putaran pada level 3 adalah 1420 rpm, gerak makan pada level 3 adalah $0,24 \mathrm{~mm}$. Umur pakai mata bor akan semakin berkurang.

\section{DAFTAR PUSTAKA}

[1] Yanuar Burhanuddin, Feni Setiawan, Suryadi wansa Harun, Helmi Fitriawan, 2015. Pemodelan Penyalaan Pada Proses Bubut Kering Magnesium AZ31 Menggunakan Jaringan Syaraf Tiruan. Prosiding SNTTM XIV, Fakultas Teknik, Universitas Lambung Mangkurat

[2] Gusri Akhyar Ibrahim, Suryadiwansa Harun, dan Ahmad R. Doni., 2015. Analisa Nilai Kekasaran Permukaan Paduan Magnesium AZ31 Yang Dibubut Menggunakan Pahat Potong Berputar. Prosiding SNTTM XIV, Fakultas Teknik, Universitas Lambung Mangkurat.

[3] Duniawan, Agus., 2014. Pengaruh Variasi Kecepatan Potong Pahat HSS Pengeboran Baja S45c/Aisi1045 Terhadap Media Pendingin Pada Uji Kekerasan Dan Stuktur Mikro. Teknik Mesin, Institut Sains \& Teknologi AKPRIND, Yogyakarta.

[4] Wibowo Dodi., Gusri Akhyar Ibrahim., dan Arinal Hamni., 2014. Pengaruh Gerak Makan Dan Kecepatan Putaran Terhadap Aus Pahat HSS Pada Pengeboran Baja ASTM A1011 Menggunakan Pelumas Minyak Goreng.. Jurnal FEMA, Fakultas Teknik Universitas Lampung.

[5] Dalimunthe, Ruslan, 2009. Pengaruh kecepatan potong terhadap umur pahat HSS pada proses pembubutan AISI 4340. Jurnal Sains dan Inovasi 5.

[6] Ansyori, Anang. 2015. Pengaruh Kecepatan Potong dan Makan terhadap Umur Pahat pada Pemesinan Freis Paduan Magnesium. Jurnal Mechanical Vol. 6 No. 1 hal 28-35.

[7] Abidin, Zaenal., 2010. Mekanisme Keausan Pahat Pada Proses Pemesinan: Sebuah Tinjauan Pustaka. Momentum, Teknik Mesin, Politeknik Negeri Semarang.

[8] Soejanto Irwan., 2009. Desain Eksperimen dengan Metode Taguchi. Edisi Pertama-Graha Ilmu; Yogyakarta.

[9] G.A. Ibrahim, C.H. Che Haron, J.A. Ghani and A. Arsyad, 2010, Taguchi optimization Method for surface roughness and material removal rate in turning of Ti-6Al-4V, International Review of Mechanical Engineering, Vol. 4, No.2.

[10] Budiman Hendri., dan Richard, 2007. Analisis Umur dan Keausan Pahat Karbida untuk 
Membubut Baja Paduan( ASSAB760) dengan Metoda Variable Speed Machining Test. Jurnal Teknik Mesin, Fakultas Teknologi Industri, Universitas Bung Hatta, Padang. 